
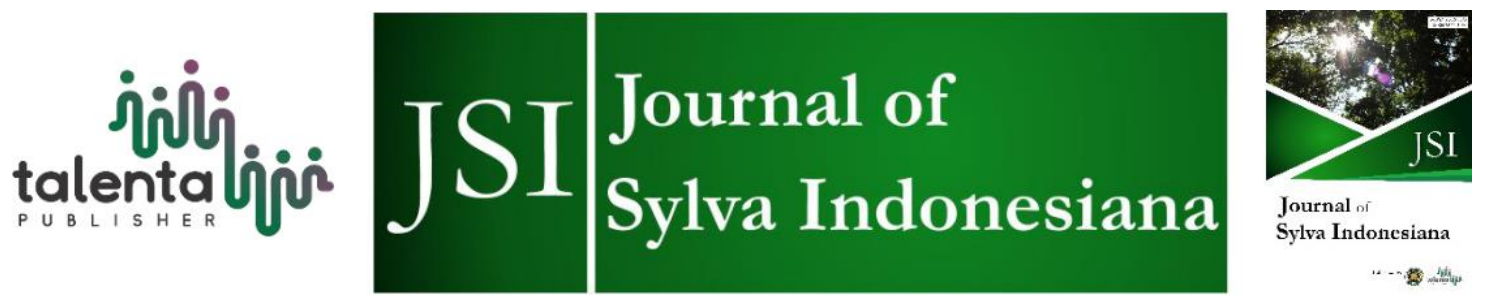

\title{
Mapping of Degraded Soil Properties in Gunung Leuser National Park
}

\author{
Paranita Asnur ${ }^{1}$, Achmad Siddik Thoha ${ }^{2}$, Deni Elfiati ${ }^{3}$ \\ ${ }^{1}$ Agrotechnology Study Program, Gunadarma University, Jl. Margonda Raya No 100, Pondok Cina, Beji. \\ Kota Depok 16424, West Java. \\ ${ }^{2,3}$ Faculty of Forestry, Universitas Sumatera Utara, Padang Bulan, Medan, 20155
}

\begin{abstract}
Deforestation causes a decrease in soil fertility. The knowledge of soil fertility in a landscape provides us information about land management. The nature of soil on each area was diversed therefore it is necessary to map the soil properties. The objective of the research was to map the properties distribution of forests land in degraded areas, namely land of a former privately owned oil palm plantation in Gunung Leuser National Park (GLNP) forest area. The study used a continuous grid interpolation method which was further formed polygons of soil properties. The soil types were inceptisol and ultisol. According to the study, most of the soils were fine-textured types, allowing surface runoff easily occurred on less vegetated areas and causing soil erosion. Soil water content on widest area was ranging from $26.98-29.50 \%$ with an area of 14.38 hectares (42.91\% of the research area). Organic materials were limited and soil $\mathrm{pH}$ was low. The study concluded that soils in the research area were less fertile. However, restoration efforts would be very possible to conduct because a amount of tree species were adaptive to soil which had low fertility.
\end{abstract}

Keyword: Degraded Land, Forest Soils, Geographic Information System, Gunung Leuser National Park.

Received 03 May 2019| Revised 08 July 2019| Accepted 15 August 2019

\section{Introduction}

Forest is a whole ecosystem unit that must be maintained and preserved. The demand of forest products continues to increase and it has been triggering forest degradation. This situation will ultimately damage of forest supporting ecology, namely forest soil properties. Deforestation has also penetrated conservation areas, including Gunung Leuser National Park (GLNP), a very important biosphere and conservation area. Land rehabilitation is one of the ways to restore the balance of GLNP ecosystem and to anticipate the damage of soil properties.

\footnotetext{
*Corresponding author at: Gunadarma University, Jl. Margonda Raya No 100, Pondok Cina, Beji. Kota Depok, 16424, West Java.

E-mail address: paranita@staff.gunadarma.ac.id
}

Copyright @ 2019 Published by Talenta Publisher 
The knowledge about soil condition and its distribution provides us its supportive ability for certain utilities, for example anticipating the damage of soil properties. Various sciences related to soil and investigation methods are developing. Soil properties can also be mapped using Geographic Information System (GIS). Nowadays, this system is also used in forestry sector to form a solid forestry database as material for making policy decisions related to forest areas.

The prediction and soil properties distribution and responses to management are a necessity on agricultural and forestry fields, feasibility study and area development project plannings, and various technical operations. To achieve these things, homogenous individual mappings is very important.

This study used GIS to map the distribution of soil properties due to the lack of information of GISbased conservation planning and land rehabilitation, in particular in Gunung Leuser National Park II Stabat SPTN VI Besitang at Sei Betung Resort, Langkat District, North Sumatra.

\section{Materials And Method}

\subsection{Materials}

The materials used in this research was soil sample from degraded land in the forest area of Gunung Leuser National Park (GLNP), map of the earth obtained from Geospatial Information Institution, the GLNP area map and laboratory examination materials.

\subsection{Observation Parameter}

The parameters of study consisted of soil texture, soil moisture, field capacity water content, soil $\mathrm{pH}$, and organic materials.

\subsection{Research Procedures}

\section{A. Field Soil Sampling}

The slopes and areal cover were assessed by using satellite imagery and considered homogenous. The study used a grid survey method. According to [1], the grid survey method is soils sampling scheme which systematically designed to consider the expected spatial autocorrelation range. The method is very suitable for intensive survey with large scale where aerial photograph interpretation is very limited and observation intensity is very dense requires placing accuracy in the field and map.

We made plots/grids and calculated area (Figure 1) where we took the samples. Plots representing soil samples were determined using simple random selection [2]. However, we used GPS to simplify and coordinate accuracy on both field and map. 


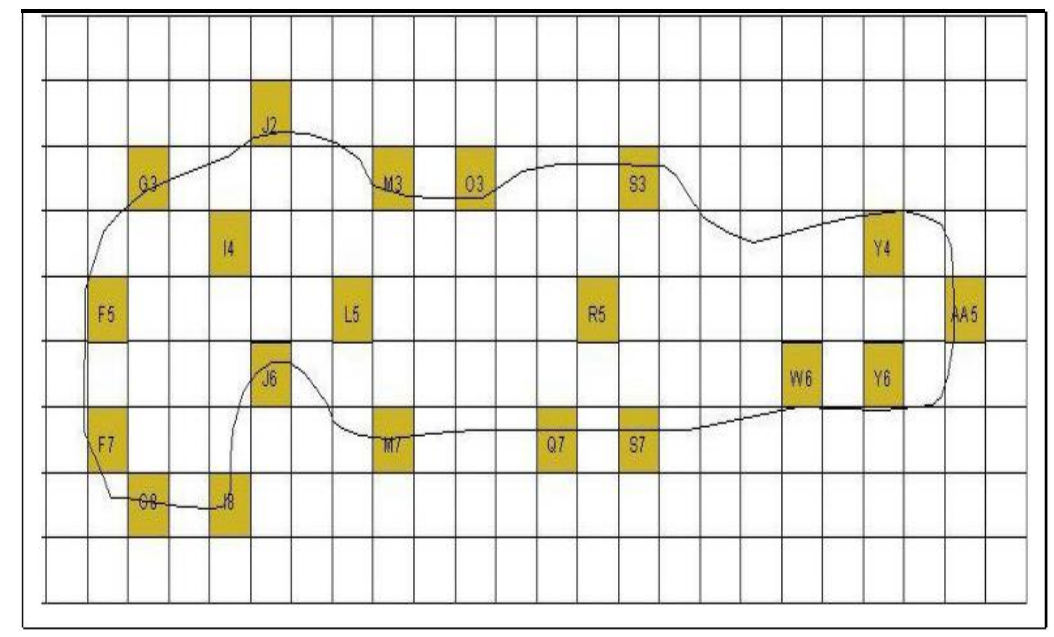

Figure 1 Soil Sampling Plots

Sampling was conducted on 20 determined plots. As much as two $\mathrm{kg}$ of soil was taken from 5-10 spots of each plot composited on site. All samples were kept in plastic bags and coordinate was recorded. Furthermore, samples were analyzed in soil laboratory.

\section{Results And Discussion}

The research was conducted in 33.5 hectares of open area overgrown with reeds and saplings of several species (Figure 2). The south side bordered with a secondary forest of GLNP and the other side borders with bushes and former area of palm oil plantation. Although once being managed by a private company, the palm oil plantation was still in the conservation area of GLNP. In general, the soil color was blackish brown. The soil types in the study area were inceptisol and ultisol [3].

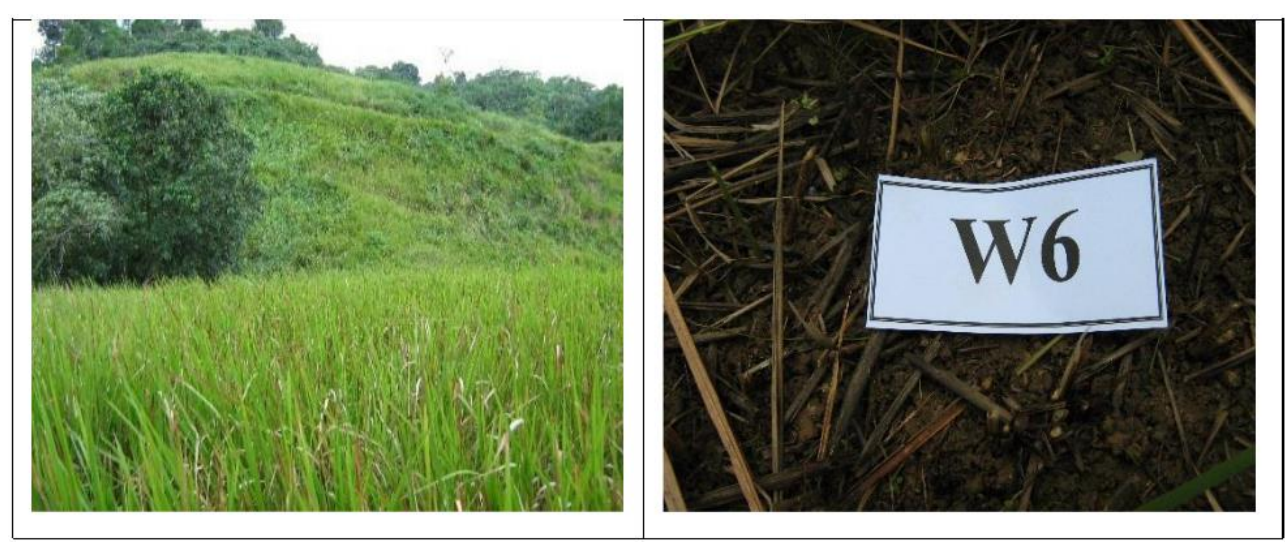

Figure 2 (a) The study area and (b) the color of soil 


\subsection{Soil Texture}

There were eight soil textures according to the distribution, namely: silty clay, silty clay loam, clay, clay loam, silty loam, sandy loam, loam, and sandy clay loam. Loam and silty loam were fine soil textured. When it's not raining, less moisture causing soil become very dry and hard. According to [4], loam contributes to water content and acts as a determining factor in soil processing. Soil with high loam will retain a large amount of moisture and inhibit soil processing.

Table 1 Soil texture and area coverage in the research site

\begin{tabular}{|c|c|c|c|c|c|c|}
\hline \multirow{2}{*}{ Soil texture* } & \multicolumn{3}{|c|}{ Fraction Comparison $(\%)$} & \multirow{2}{*}{$\begin{array}{l}\text { Area } \\
\text { (ha) }\end{array}$} & \multirow{2}{*}{$\begin{array}{l}\text { Area } \\
(\%)\end{array}$} & \multirow{2}{*}{$\begin{array}{l}\text { Texture Grouping } \\
\text { (Rayes, 2007) }\end{array}$} \\
\hline & Sandy & Silt & Loam & & & \\
\hline Silty Clay & $0-50$ & $50-88$ & $0-27$ & 1.470 & 4.39 & Medium \\
\hline Silty Clay loam & $0-20$ & $40-73$ & $27-40$ & 4.785 & 14.28 & Medium fine \\
\hline Clay & $23-52$ & 2850 & $7-27$ & 7.157 & 21.36 & Medium \\
\hline Clay Loam & $20-45$ & $15-53$ & $27-40$ & 10.295 & 30.73 & Medium fine \\
\hline Silty Loam & $0-20$ & $40-60$ & $40-60$ & 8.926 & 26.64 & Fine \\
\hline Sandy Clay & $43-80$ & $0-50$ & $0-20$ & 0.864 & 2.58 & Medium coarse \\
\hline Loam & $0-45$ & $0-40$ & $40-100$ & 0.003 & 0.01 & Fine \\
\hline Total & & & & 33.5 & 100 & \\
\hline
\end{tabular}

*Source: Staff of Center of Soil Research (1983) cited in [5].

According to [6], the upper layers of soil $(0-30 \mathrm{~cm})$ are grouped into five classes, namely fine, medium-fine, medium, medium coarse, and coarse. If the soil on the study area classified according to this statement, the texture classifications were distributed as follows: fine, medium-fine, medium, and medium coarse.

The distribution of soil texture is vital because it indicates the soil ability to retain water and organic materials. Compared to soil with a coarse texture, soil with fine to medium-fine texture has the capability to retain water and organic materials and prevent them from being leached. Fine-textured soil has smaller and fewer pores. On the contrary, coarse-textured soil contains bigger and more pores, allowing water and nutrients to escape to the lower horizon. 


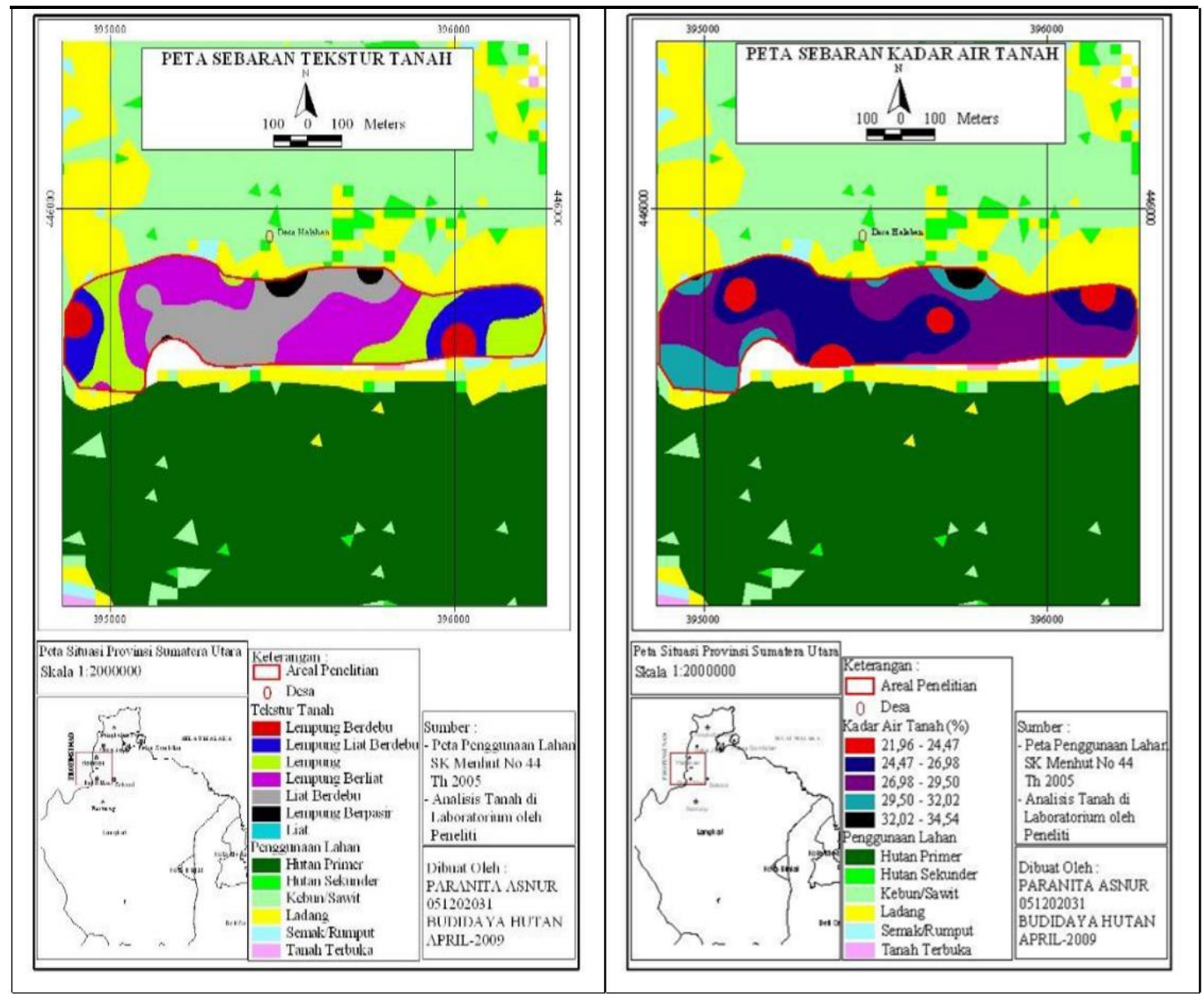

Figure 3 (a) Soil texture, (b) Soil moisture

According to [7], the sand has a small surface area but large in size. If the percentage of sand in the soil is high, the pores between particles also increase, accelerating more air and water. The $2.53 \%$ research area with sandy clay texture (medium-coarse) will require good processing management due to its large pores. Water and nutrients will easily be leached on this type of soil. According to [1], the main problem with sandy soil is its ability to hold water and nutrients. Therefore, they will not easily escape to the lower horizon. For that reason, special handling needs to be applied, for example by the organic materials augmentation in order to bind water and nutrients. According to [8], the fine to sandy with clay content more than $50 \%$ (which was the dominant texture in the research area) allows the red meranti (Shorea leprosula) and khaya (Khaya antoteca) to grow [9]. These species are able to grow in the open area, inceptisol soil, and landscape with slopes and hills.

\subsection{Soil Moisture}

The distribution of soil moisture is presented in Figure 3b. Soil moisture also depends on soil texture. Soil containing a lot of sandy fraction will allow water easily to escape due to its poor holding capacity. This supports [1] who stated that the amount of moisture retained in soil pores vary to its degree of strength and holding capacity, and depend on available water and the size of pores. Soil 
ability to absorb water is affected by vegetation above. The denser of vegetation the higher soil ability to absorb water [10].

Table 2 The range of soil moisture (\%) and area coverage in the research site

\begin{tabular}{lll}
\hline \multicolumn{1}{c}{ Range* } & Area (ha) & Area (\%) \\
\hline $21.96-24.47$ & 2.38 & 7.12 \\
$24.47-26.98$ & 12.36 & 36.88 \\
$26.98-29.50$ & 14.38 & 42.91 \\
$29.50-32.02$ & 3.80 & 11.34 \\
$32.02-34.54$ & 0.58 & 1.75 \\
\hline Total & 33.5 & 100 \\
\hline
\end{tabular}

Water is vital for the growth and the performance of plants and soil organisms to carry nutrients needed by microorganisms and plant's roots [4]. The type and distribution of vegetation can be affected by the amount of water content in the soil, depended on the plant's level of tolerance to soil moisture. The distribution of vegetation in the earth's surface is controlled by the availability of water in the soil [1].

\subsection{The Water Content of Field Capacity}

The distribution of field capacity in the range of $42.24-49.329 \%$ has the texture of sandy clay and classified as medium-coarse (Figure 4a). Water is predicted to easily escape to lower horizon, causing water to dry quickly and inhibit roots to get water.

Table 3 The range of water content of field capacity (\%) in the research area

\begin{tabular}{ccc}
\hline \multicolumn{1}{c}{ Range* } & Area (ha) & Area (\%) \\
\hline $20.97-28.06$ & 1.16 & 3.47 \\
$28.06-35.15$ & 3.98 & 11.86 \\
$35.15-42.24$ & 9.71 & 28.99 \\
$42.24-49.32$ & 13.32 & 39.76 \\
$49.32-56.42$ & 5.33 & 15.91 \\
\hline Total & 33.5 & 100 \\
\hline
\end{tabular}

The range of water content of field capacity is also affected by soil texture and organic material. Medium-coarse textured soil or soil with large pores keep failing to bind water. Low content of organic material also promotes continuous water loss. According to [1], soils with large pores will never reach their field capacity due to continuously losing water. 


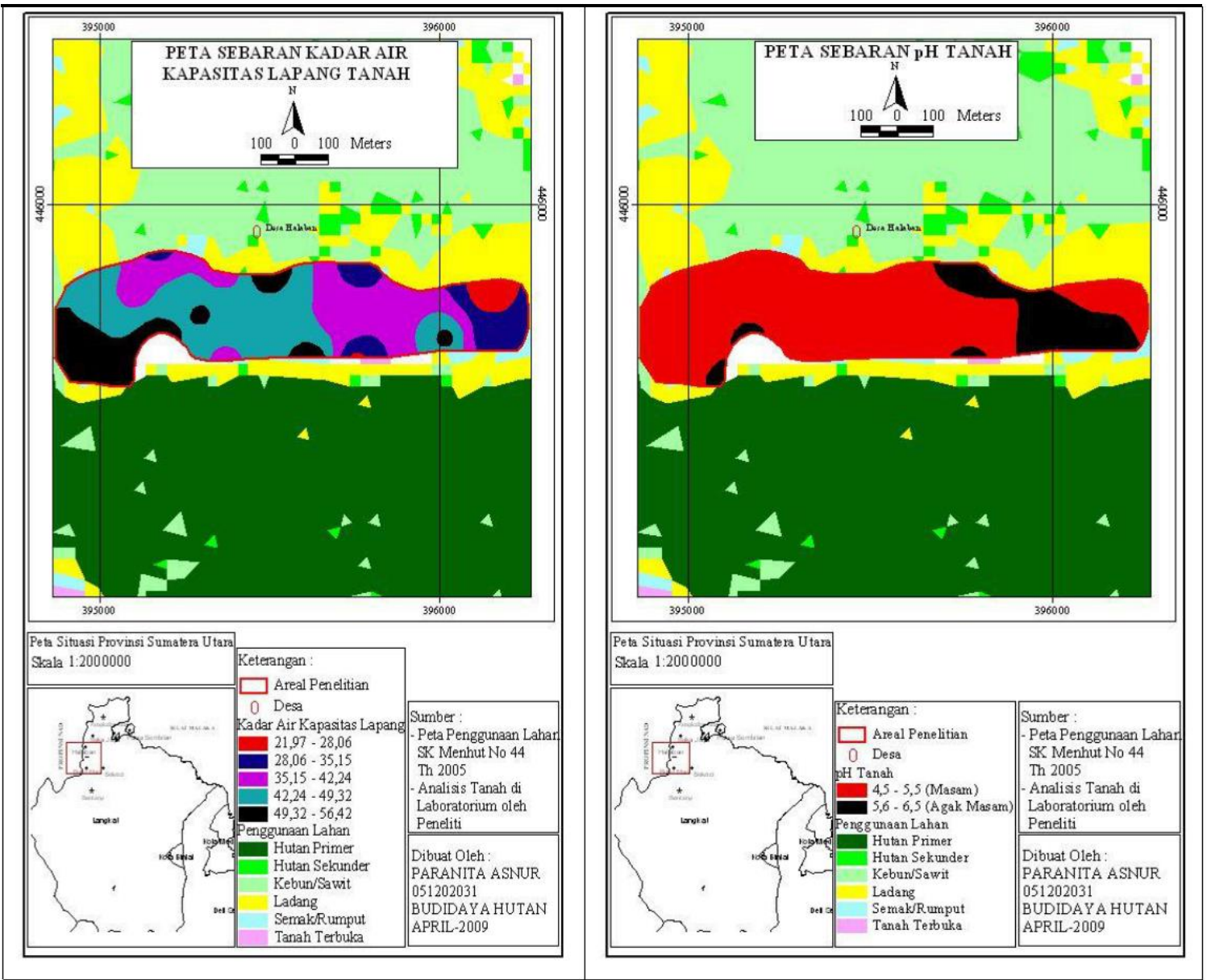

Figure 4 (a) The distribution of water content of field capacity and (b) The distribution of soil $\mathrm{pH}$

\subsection{Soil pH}

The distribution of soil $\mathrm{pH}$ dominated by acid soils because the site was an open area which has been degraded, indicated with abundant of the reeds which inhibit the growth of other competitors. Forestry species were able to grow in $\mathrm{pH}$ range of 4.5 to 6.5. According to [4], rubber plant (Hevea brasiliensis) is capable to live on soil with a $\mathrm{pH}$ range of 4.0 to 8.0 and grow best in the $\mathrm{pH}$ range of 5.0 to 6.0. Meranti merah (Shorea leprosula) on $\mathrm{pH}$ range of 5.5 to 6.5, durian (Durio zibethinus) on $\mathrm{pH}$ range of 5.5 to 6.5 and Khaya (Khaya anthotheca) on $\mathrm{pH}$ range of 4.3 to 6.4. Considering of this, reforestation on the open area in research site was possible.

Table 4 The range of soil $\mathrm{pH}$ in the research area

\begin{tabular}{llll}
\hline $\mathrm{pH}$ range $\left(\mathrm{H}_{2} \mathrm{O}\right) *$ & Criteria* & Area (ha) & Area (\%) \\
\hline $4.5-5.5$ & Acid & 26.80 & 80.00 \\
$5.6-6.5$ & Medium acid & 6.70 & 20.00 \\
\hline Total & & 33.50 & 100.00
\end{tabular}

*Source: Staff of Soil Research Center (1983) cited in [5] 
The distribution of soil $\mathrm{pH}$ affected by several factors, such as leaching caused by rainfall on an area with a lack of vegetation or rooting system. When this occurred, rainwater or surface flow extracted organic materials on topsoil and carried them away. The calcium content on the soil will decrease. This was in line with [4], who stated that rainfall on the wet tropical rainfall region is an important factor to affect the soil acidity on the area. Rain washes away limes and bases to lower horizon, passes through the rooting system area.

The used of acidy fertilizer also affects the distribution of soil $\mathrm{pH}$. The research site was a former private palm oil (Elaeis gueneensis) plantation, which was very possible to have overdosed fertilizing. The acid properties on the fertilizer could accumulate in the soil and causing the low $\mathrm{pH}$. According to [4], the use of fertilizer such as ammonium sulfate and ammonium nitrate could be the cause of soil acidity.

\subsection{Organic Materials}

Organic matter is directly proportional to the content of organic C-soil. The higher the content of soil organic $\mathrm{C}$, the higher the value of soil organic matter. The results of data analysis are presented in figure 5. The content of C-organic in the soil is very low to moderate (Table 3).

Table 5 The range of soil C-organic (\%) in the research area

\begin{tabular}{cccc}
\hline Value* $^{*}$ & Criteria* & Area (ha) & Area (\%) \\
\hline$<1.00$ & Low & 0.35 & 1.04 \\
$1.00-2.00$ & Medium & 24.49 & 73.08 \\
$2.01-3.00$ & High & 8.67 & 25.88 \\
\hline & & 33.50 & 100
\end{tabular}

*Source: Staff of Soil Research Center (1983) cited in [5].

The result showed that the distribution of soil C-organic was on the range of $0.94-5.14 \%$, indicating the various levels of soil fertility in the research area. Organic materials generally found on the soil surface [10]. The amount is only about 3 to $5 \%$ but significantly influence soil properties. The decrease in the content of organic matter in the soil is caused by the harvesting of wood/trees, burning of plant residues, increasing decomposition and return of bad C-Organic. The content of organic matter shows the relationship between abiotic and biotic components [12].

The decrease of organic material sources production, including litter from the forest or other plants allow the organic matter content in the soil to be very low. According to [1], the amount of organic matter added to the soil depends on natural soil cover. The addition of organic material naturally comes from forests, cultivated plant residues, and grasslands. Changes in land governance will reduce 
organic content, $\mathrm{N}$, and $\mathrm{P}$ [13]. According to [14], if the land converted into oil palm plantations, the improvement of organic matter continues for sixteen years but the nutrient content will not be the same as forest soil.

In general, the properties of the soil in the study area were of infertile nature, because they had a low organic matter content and had an acidic soil $\mathrm{pH}$. In addition, the properties of the soils were dystropepts (infertile inseptisols), hapludults (ultisols with simple horizon), humitropepts (inseptisols with humus content in the tropics), and tropaquepts (continuously flooded inceptisols in the tropics). These soil types had a low level of soil fertility [6].

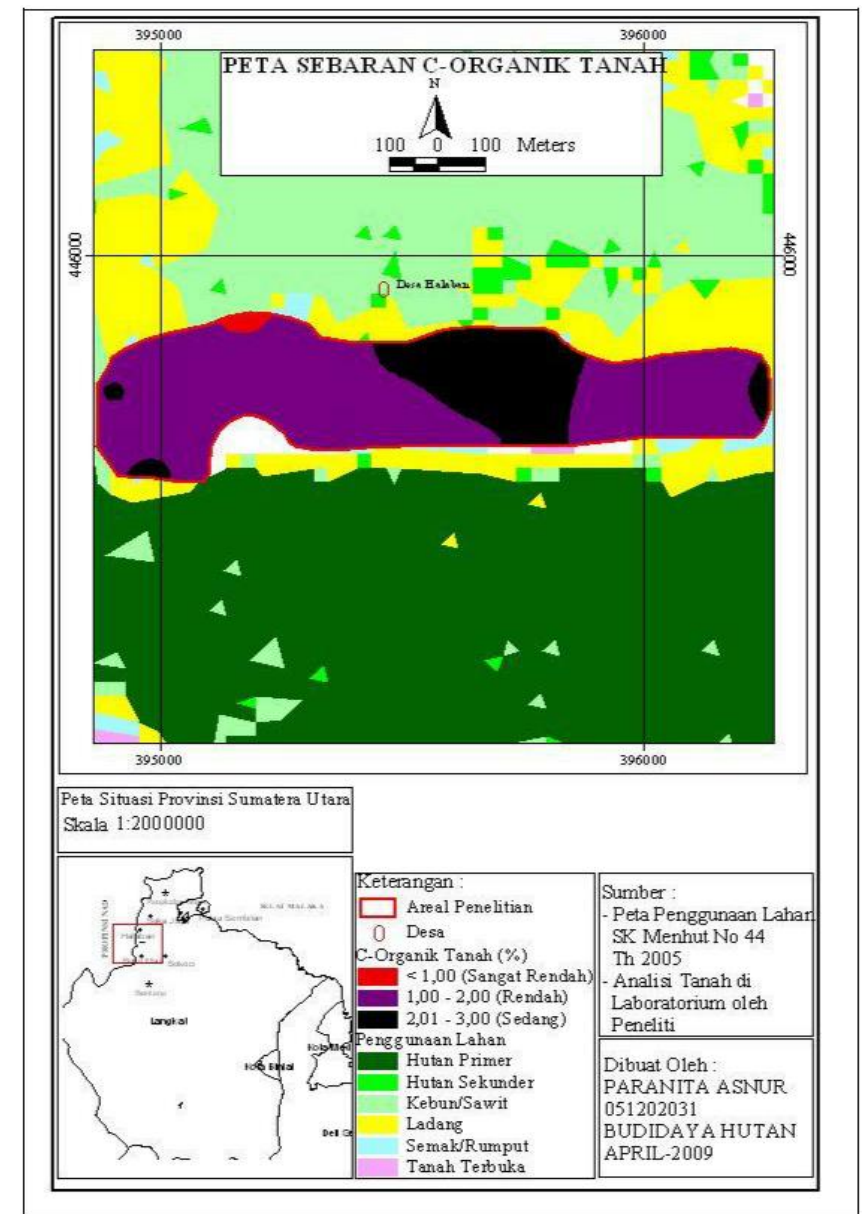

Figure 5 Distribution of soil C-organic in the research area.

Even though the organic matter content and acidic $\mathrm{pH}$ was low, these properties stillcould be tolerated by forestry plants and they will grow well in these conditions. However, a decrease in soil fertility may continue to occur if no response or improvement is made to the environment that affects changes in soil properties. For example, the research area was abandoned without any rehabilitation process. It will stimulate a decrease in soil fertility. In addition, the research area was also hilly due to the fact that the soil will easily erode [15] along with surface runoff because there were no plant roots that 
functioned to bind aggregate soil. Therefore, biological conservation techniques need to be done immediately to stop the land degradation process [16].

\section{Conclusion}

The soil texture was dominated by dusty clay, the content of soil water content was 26.98 to $29.50 \%$ and field capacity was 42.24 to $49.32 \%$. The soil $\mathrm{pH}$ was low and organic materials were limited. The low soil $\mathrm{pH}$ was a limitation of soil fertility. Steep topography and open land cover caused the land to degrade due to ongoing surface erosion. Restoration efforts are very possible because some tree species are very adaptive to low soil fertility.

\section{REFERENCES}

[1] A. Saidi, Soil Physics and the Environment, Andalas University Press, Padang, 2006.

[2] K. A. Gomez and A.A. Gomez, In: Endang Sjamsuddin and Justika S (Eds), Baharsjah.Statistical Procedures for Agricultural Research, $2^{\text {nd }}$ edition, University of Indonesia Publisher, Jakarta, 1995.

[3] (YLI) Yayasan Leuser Indonesia, Map of Land and Land of Besitang District, Langkat Regency, Banda Aceh, 2008.

[4] L. Musa, Mukhlis, and R. Abdul, "Basic Soil Sciences (Fundamentals of Soil Science)," Department of Soil Sciences, Faculty of Agriculture, University of North Sumatra, Medan, 2006.

[5] Mukhlis, "Soil Chemistry," Department of Soil Sciences, Faculty of Agriculture, University of North Sumatra, Medan, 2004.

[6] L. Rayes, Method of Inventory of Land Resources, Andi Yogyakarta, Yogyakarta, 2007.

[7] N. Hakim, M.Y. Nyakpa, A. M. Lubis, S. G. Nugroho, M. A. Diha, G. B. Hong, H. H. Bailey, Basics of Soil Science, University of Lampung. Lampung, 1986.

[8] (OIC) Orangutan Information Centre, "Save Sumatran Orangutan from Extinction," [Online]. Available: http://www.orangutancentre.org. [Accessed: 25 Mei 2009].

[9] Dephutbun. Indonesian Forestry Guidebook. Forestry and plantation research and development agency. Jakarta. 1998.

[10] J. Volk, W. Barker, dan J. Richardson, "Soil Health in Relation to Grazing," Range Science and Soil Science Department, [Online]. Available: http://www.ag.ndsu.nodak.edu/ street/ 2003report/ Soil\%20 Health\% 20in\%20Relation\%20to\%20 Grazing.htm. 2003.

[11] S. Hardjowigeno, Soil Science, Akademika Pressindo, Jakarta, 2003.

[12] S. Rahmah, Yusran, H. Umar, "Soil Chemical Properties in Various Types of Land Use in Bobo Village, Palolo District, Sigi Regency," Jungle News ISSN: 2406-8373, vol. 2, no. 1, pp. 88-95, June 2014.

[13] B. Wasis, "Comparison of Chemical and Biological Properties of Soil Due to Openness of Land in the Reforestated Pine Forest," Journal of Tropical Silviculture, vol. 3, no. 1, 2012.

[14] Oksana, M. Irfan, and M. Utiyal, "Effect of the Function of Forest Land Transfer to Oil Palm Plantation on the Chemical Properties of Soil," Journal of Agrotechnology, vol. 3, no. 1, pp. 2934, 2012.

[15] B. H. Prasetyo and D. A. Suriadikarta. Characteristics, Potential, and Ultisol Soil Management Technology for the Development of Dry Land Agriculture in Indonesia. Journal of Agricultural Research and Development, 25 (2), 2006.

[16] A. Yamani, "Study of Soil Fertility Levels in Sebatung Mountain Protected Forest in Kotabaru Regency, South Kalimantan," Forest Journal Tropis, vol. 11, no. 29, 2010. 